\title{
The Development of Cooperation Model for Protection and Care for Students under the Thailand Office of the Basic Education Commission
}

\author{
El desarrollo del modelo de cooperación para la protección y el cuidado de los estudiantes \\ dependiente de la Oficina de la Comisión de Educación Básica de Tailandia
}

\author{
WONGSIRASAWAT, Chanchai ${ }^{1}$ \\ PUPAT, Phadungchai ${ }^{2}$ \\ BHAWANGKANANTHA, Thira ${ }^{3}$
}

\begin{abstract}
This paper reports the development of cooperation model for protection and care for students under The Thailand Office of the Basic Education Commission (OBEC). Consistent of 4 parts as follows: 1) background, concepts and the objectives of the model 2) model's components in three levels as the policy, the driven forced, and operating level 3) guidelines for using this model and 4) conditions for success. Experts have the overall opinion that the model is accurate, appropriate, feasible and useful. Key words: cooperation model, protection, care, thailand office of the basic education commission

\section{Resumen}

Este documento presenta el desarrollo de un modelo de cooperación para la protección y el cuidado de los estudiantes dependiente de la Oficina de la Comisión de Educación Básica de Tailandia (OBEC). El cual consta de 4 partes: 1) Antecedentes, conceptos y objetivos del modelo 2) componentes del modelo en tres niveles como el nivel de política, el nivel impulsado forzado y el nivel operativo 3) pautas para el uso y 4) condiciones para el éxito. Los expertos tienen la opinión general de que el modelo es preciso, apropiado, viable y util.

Palabras clave: modelo de cooperación, protección, cuidado, oficina de la comisión de educación básica
\end{abstract}

\section{Introduction}

Under the Royal Guidance of His Majesty King Rama IX in the commencement ceremony Srinakharinwirot University Prasanmit Tuesday 28 November 1972 (Thailand). The Office of the Basic Education Commission (OBEC) adopted the above mentioned royal speech as an important policy in the implementation of the protection and care for students since March 2014 by giving all educational institutions provide a strong student care system continues to work towards sustainability for helping students effectively in all dimensions especially the changing of students' behavior ( Office of the Basic Education Commission, 2014). That matches the Child

\footnotetext{
${ }^{1}$ Valaya Alongkorn Rajabhat University under the Royal Patronage, Pathum Thani 13180, Thailand owen_toto@yahoo.com ; wochanchai@gmail.com

${ }^{2}$ Faculty of Industrial Education and Technology, King Mongkut's Institute of Technology Ladkrabang, Bangkok 10520, Thailand

${ }^{3}$ Office of the Basic Education Commission (OBEC), Dusit Bangkok 10300, Thailand
} 
Protection Act of 2003 which stipulates that schools and educational institutions must provide a system of work and activities in advising, training students and parents in order to promote suitable behavior and social responsibility and give safety to students with the specific criteria, methods and conditions stipulated in the ministerial regulations to provide students with appropriate behavior and social responsibility and the safety of students as well. Students must behave in accordance with the rules of the school or educational institution. (Ministry of Social Development and Human Security, 2007)

The formal school education is a study system that determines the purpose, method of study, curriculum, duration of the study, evaluation systems, and graduation requisites. The primary and secondary education (Grade 1 to Grade 12) and higher education, most of the educational institutions in Thailand provide education by formal school education Non-formal education is a flexible study of the purpose, the model of educational management method, and the duration of the study. The content and curriculum are designed to be appropriate to the problems and needs of each student group. It is widely promoted as lifelong learning. (Phucharoen, 2019)

Nowadays, access to education is almost everywhere in Thailand, The 21st century is a challenging time for humanity in modern society. The rapid growth of information technology has connected every region of the world without boundaries including learning in the digital age in the era of Thailand 4.0 that is both beneficial and harmful to students. It is an era in which Thailand is faced with rapid changes. The advances of information technology have made the world smaller, smarter and easy to connect as well. The 21st century's lifestyles are completely different from the 19th and 20th centuries. The Development plan National Economy and Society Issue 12 (2017 - 2022) aiming to raise the quality of human resources of all ages to grow quality having good social values, having a good discipline and awareness of social care as a whole. That has been defined vision Thailand is a stable, prosperous, and sustainable developed country with development according to the sufficiency economy philosophy. (Office of the National Economic and Social Development Board, 2016).

To Ensure that the students' safety is the most important role of the educational institution checks must be performed by providing in accordance with the context of the educational institutions, school administrators, and also teachers are the most important people that can drive a movement to protect and care for students. Therefore, in order to encourage and develop students to improve to their safety by asking the cooperation from many sectors to make sure about safety to the students to have their full potential development by arranging safety in their daily life including protecting, and caring them from various physical and mental states. Providing safety to students has an effect on the quality of learning of students and they can live happily in society which will lead to the development of a good life and also is an important encouragement for the development of the country in the near future. (Office of the Basic Education Commission, 2016)

According to the above mentioned, the OBEC Student Protection Task Force Center (SPTFC) was founded by the OBEC that is a special center to protect and care for students in the fiscal year 2012 in order to have a specific agency working on the protection and care for students in the fiscal year 2017. It researched the performance of the protection and care for students. The Office of the Educational Service Area and the Specialized Child Protection and Care Center received the report from the Office of Educational Service Area with 193 from 255 (85.77\%) and the reported from the Primary Educational Service Area of 156 out of 183 districts or (85.25\%), the reported from the Secondary Educational Service Area Of 37districts from 42 districts or (88.10\%) including one reported from SPTFC. Situation to Care of Thai Children Also has scattered depending on the interests and abilities of the childcentered agency. However, each department has its own main mission. Therefore, there is a lack of sufficient systematic movement in the work that is related to the child. Therefore, the movement in the child still lacks the movement that is systematic enough. The conditions and guidelines for child protection and care for students under the OBEC that are related to the management process show a lack of continuity and link between policy-level structures, driven level and practical level. It's not covered by guidelines which leads the practitioners to get a lack 
of knowledge and understanding in implementing of information program under the name of the Social Aid Center or One-Stop Crisis Center (OSCC). The results of the continuation in working that affects the promotion and development still lacks flexibility and unity. They're not covered by guidelines of participation with all sectors. They were not continuously covered by guidelines of the positive monitoring aspect involved in the management process. The demand of work found that the needs of policy-level operating want the operator to be able to solve the problems that arise with the child in time that can students effectively. The area practitioners wanted to the students in the area by the cooperation of the relevant departments in the area in order to increase the confidence of the working performance of the workers. (Thira Bhawangkanantha, 2016)

Based on the above points protecting and helping students at risk by arranging a system and procedures that focus on the benefits of students matching with the law, and the standardized practice relies on driving, supervision and monitoring in the implementation of the protection and care for students. There are standardized forms, tools and procedures available to use for helping students. Therefore, it is necessary to develop a cooperation model for protection and care for students under the OBEC that can be put to practice in order to decrease problems.

\section{Methodology}

The development of cooperation model for protection and care for students under the OBEC is a research that focuses on research and development. There are 2 steps of research methodology are as follows:

Step 1: Study of guidelines for cooperation in the operation of protection and care for students under the Office of the Basic Education Commission from in-depth interviews. The group of informants selected by purposive sampling consist of 15 practitioners in the protection operation and care for students that within the administrative structure which consists of 5 Senior executives holding positions in the educational administration structure of OBEC, 5 directors of Education Promotion Group in OBEC, and 5 school administrators selected from educational institutions with excellent performance. The research instrument were semi-structured interview forms. The open-ended questions were focus on two important aspects are management and operational in 5 aspects strategies: 1) Prevention, 2) Child Protection, 3) Development and Promotion, 4) Participation in all sectors, and 5) Follow-up by positive monitoring . Data analysis based on content analysis.

Step 2: Design and examine the cooperation model for protection and care for students under the Office of the Basic Education Commission which was conducted in 2 sub-steps as follows:

2.1. Synthesize the results from in Step 1 and studies of information current operations from related documents on performance according to the Ministry of Education's policy, annual budget performance report of the OBEC, school self-assessment report, etc., after that design a model for cooperation in the protection and care for students under the Office of the Basic Education Commission.

2.2. Examine the cooperation model for protection and care for students under the Office of the Basic Education Commission by using focus group discussion consist of 15 experts who have worked and got experience in protection and care for students under the Office of the Basic Education Commission which consists of 2 executives administrators , 3 directors of the educational service area, 2 school administrators, 2 staff members of the educational management promotion group, and 6 government officers by purposive sampling. The research instruments used for the data collection were record forms and the accurate, appropriate, feasible and useful assessment forms to evaluate the cooperation model for protection and care for students under the OBEC. Data analysis was content analysis. 


\section{Results}

From results can be summarized as follows:

1. Guidelines for cooperation to protect and care for students under the Office of the Basic Education Commission. It was found that in the part of the ministry level policy, there should be an action framework to lead the practitioners to perform and apply to the operations in order to carefully coordinate, protect and surveil the students. This works like a system to run the task in the regional area and be able to coordinate the service in accordance with the guideline policy framework as a mission to school practitioners to follow the structure for the workers in the working area in time correctly. And additional suggestions on education, operating conditions, protection and care for students. There should be a specific strategic plan from OBEC.

\section{The cooperation model for protection and care for students under the Office of the Basic Education}

Commission. The researcher has determined the structure and relationship from the components of the study which consists of 4 parts: 1) the introduction part consists of the background, concepts and the objectives of the model. 2) the model components including the policy level, driving force level, and operational level. 3) Guidelines for the implementation of the model. 4) conditions for success. By the opinion of the experts about the model is accurate, appropriate, feasible and useful. (Figure 1).

Figure 1

Diagram of cooperation model for protection and care for students

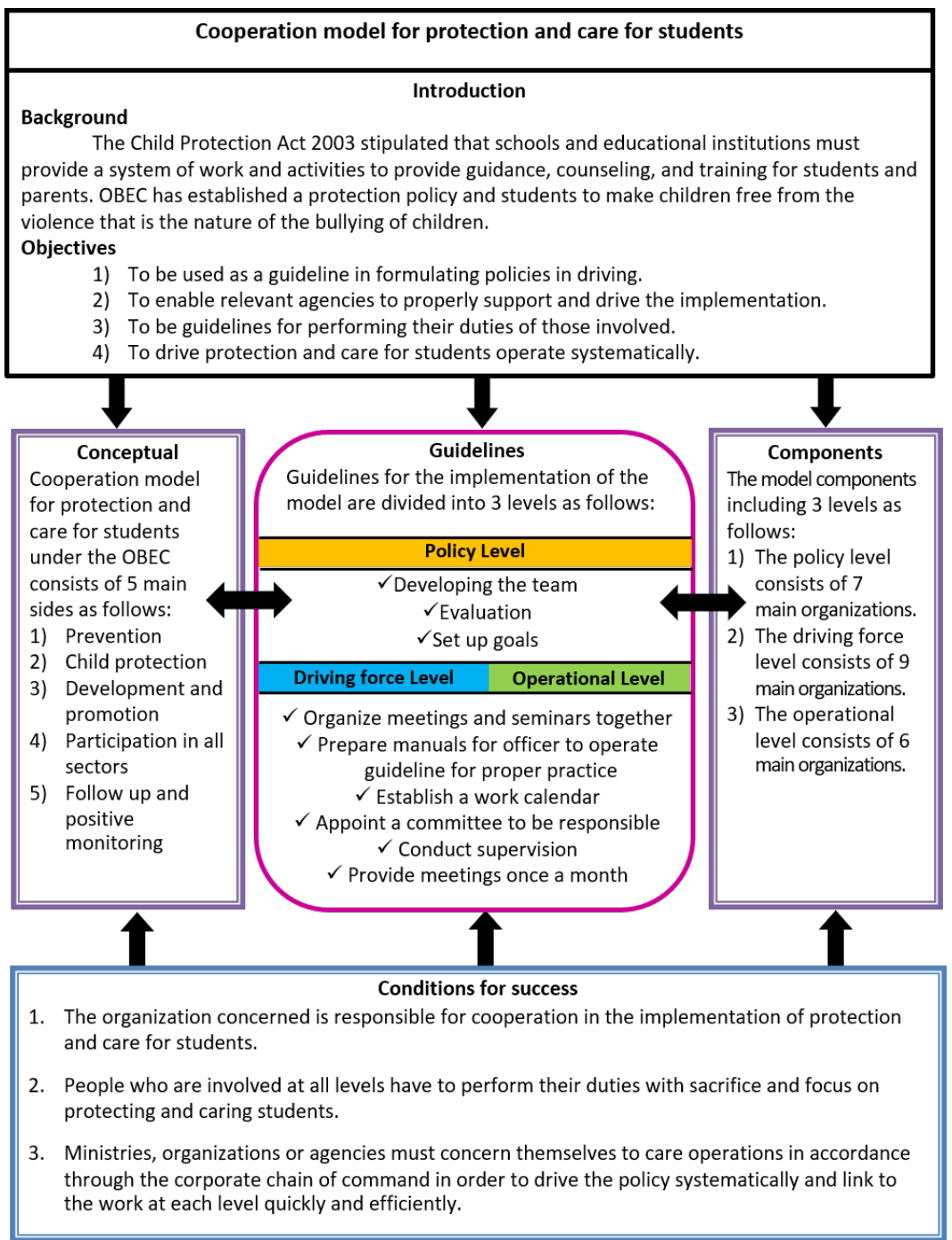


The details the cooperation model for protection and care for students under the Office of the Basic Education Commission as follows:

\section{Part 1: Introduction}

\subsection{Background}

The Child Protection Act 2003 stipulated that schools and educational institutions must provide a system of work and activities to provide guidance, counseling and training for students and parents to promote appropriate conduct and social responsibility and safety for students and students. The Office of the Basic Education Commission has established a protection policy and students to make children free from the violence that is the nature of the bullying of children. Improper punishment by teachers and school personnel and sexually harassed by friends or teachers or school personnel.

From the problems and importance, the special purpose center for the protection and care for students under the Office of the Basic Education Commission as an organization to protect and care for students. Therefore developed a cooperation model for protection and care for students under the Office of the Basic Education Commission. In order to get the form of a working group with regulating duties promote and support educational institutions and related agencies at all levels promote and support educational institutions to be able to take effective measures to prevent, protect and develop children from violence and abuse.

\subsection{Conceptual principles of the cooperation model for protection and care for students under the Office of the Basic Education Commission consists of 5 main sides as follows}

1.2.1 Prevention

1.2.2 Child protection

1.2.3 Development and promotion

1.2.4 Participation in all sectors

1.2.5 Follow up and positive monitoring

\subsection{Objectives of the model}

1.3.1. To be used as a guideline in formulating policies in driving the protection and care for students under the Office of the Basic Education Commission.

1.3.2. To enable relevant agencies to properly support and drive the implementation of protection and care for schoolchildren and facilitates the operations of the operator at the operational level.

1.3.3. To be guidelines for performing their duties of those involved. Build confidence in working efficiently and making the most of the students.

1.3.4. To drive protection work and students to operate systematically. Operations can be tracked and have data back information for planning, driving and setting the driving policy.

\section{Part 2: The model components}

The model components including 3 levels:

2.1. The policy level consists of 7 main organizations that have their duty to set up the policies to the Ministry of Education/ OBEC (Center of OBEC), Ministry of Justice (Department of Juvenile Observation and Protection), Ministry of Social Development and Human Security, Royal Thai Police, Ministry of Public Health (Department 
of Mental Health), Ministry of Interior, Other related agencies Non-Governmental Organizations (NGOs)/ Independent agencies (Mass communication Organization, and Foundations) (Figure 2).

Figure 2

Diagram of policy level

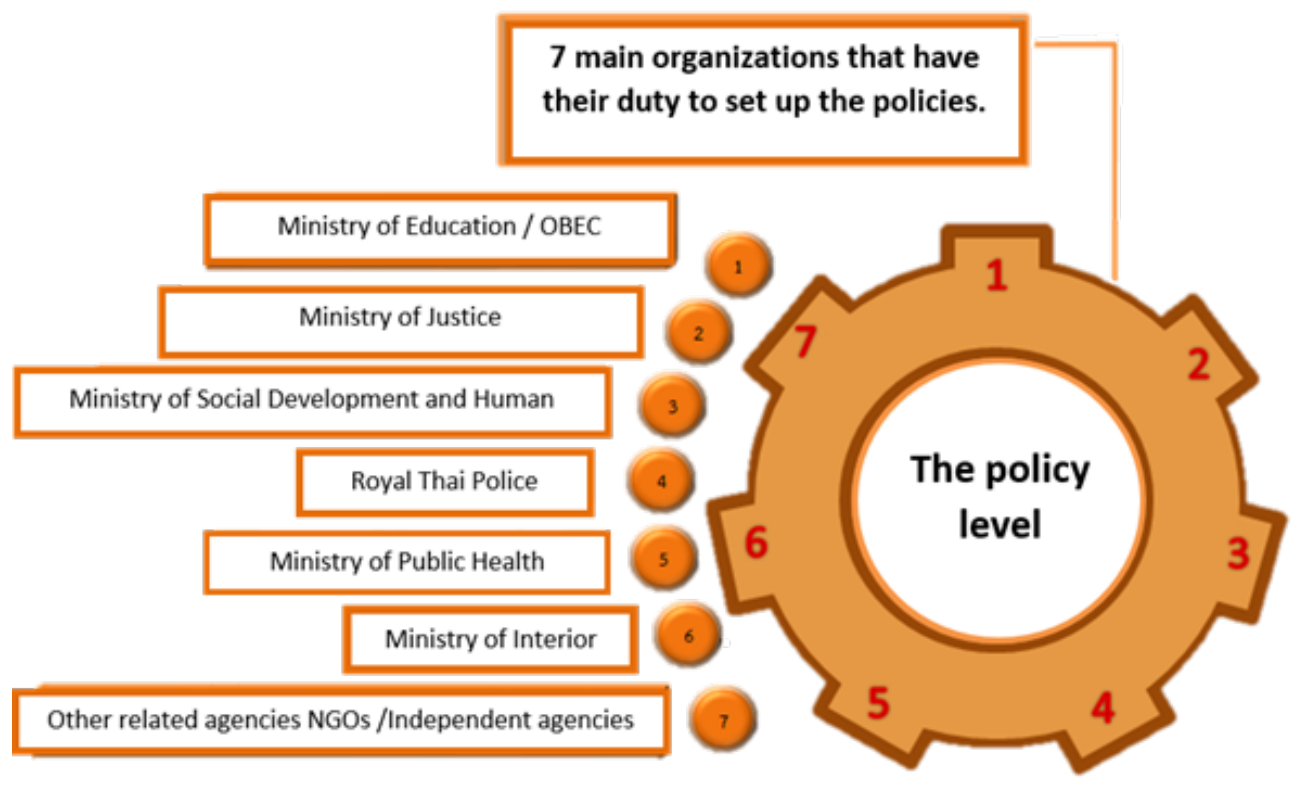

2.2 The driving force level consists of 9 main organizations of the policy to coordinate the implementation of policies for protection and care for students into the operational level such as the Educational Area, Provincial Justice Office, Provincial Social Development and Human Security Office, Police station of province or district, Provincial or district health, Provincial governor or district -chief officer, Nonprofit organizations (Red Cross Group, Foundations, Religious Organizations), Local Government Organizations (Subdistrict Administrative Organization (SAO)/Municipality), Shelter for Children and Families (Figure 3).

Figure 3

Diagram of driving force level

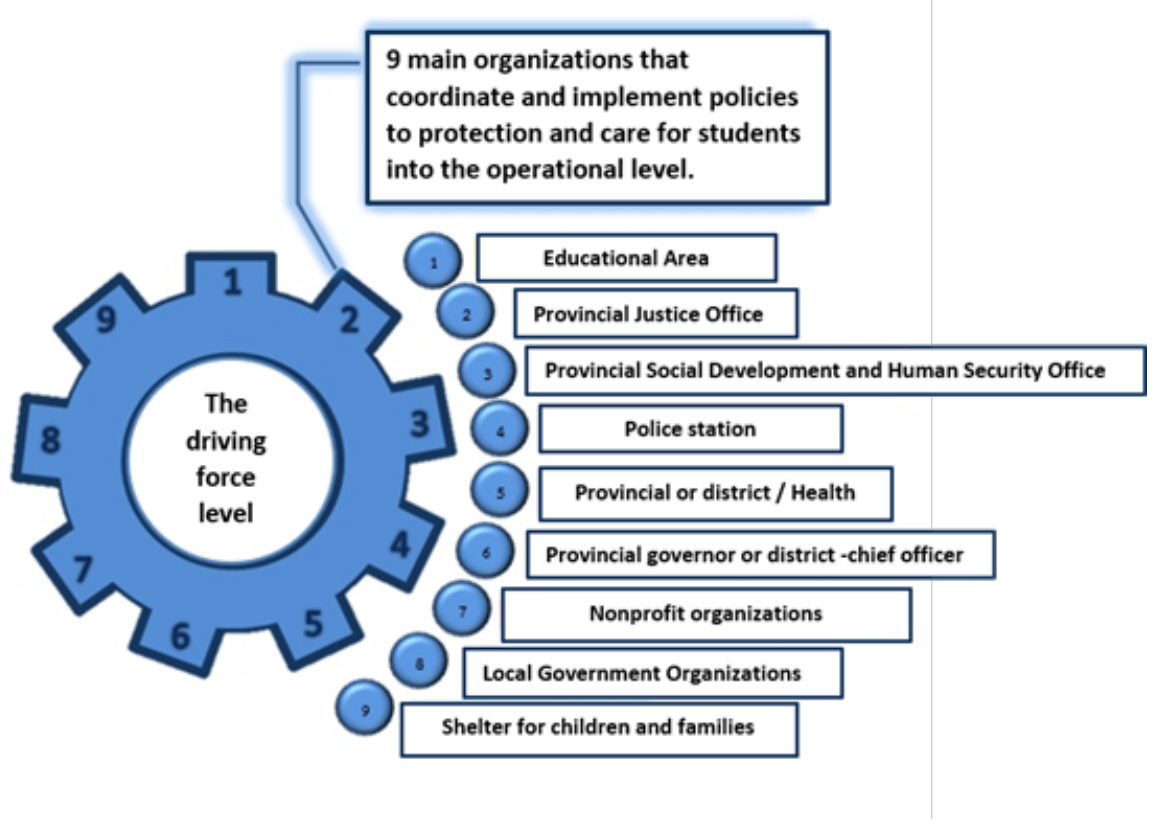


2.3 The operational level consists of 6 main organizations for the implementation of the policy to protect and care for students in accordance to the cooperative roles such as the school directors/ class teacher/ school committees and parents network, Social Development and Human Security Officers, Police officers, Village Health Volunteers, Civil Defense Volunteers, Local Government Organizations (SAO/Municipality/another organizations in community)(Figure 3).

Figure 3

Diagram of operational level

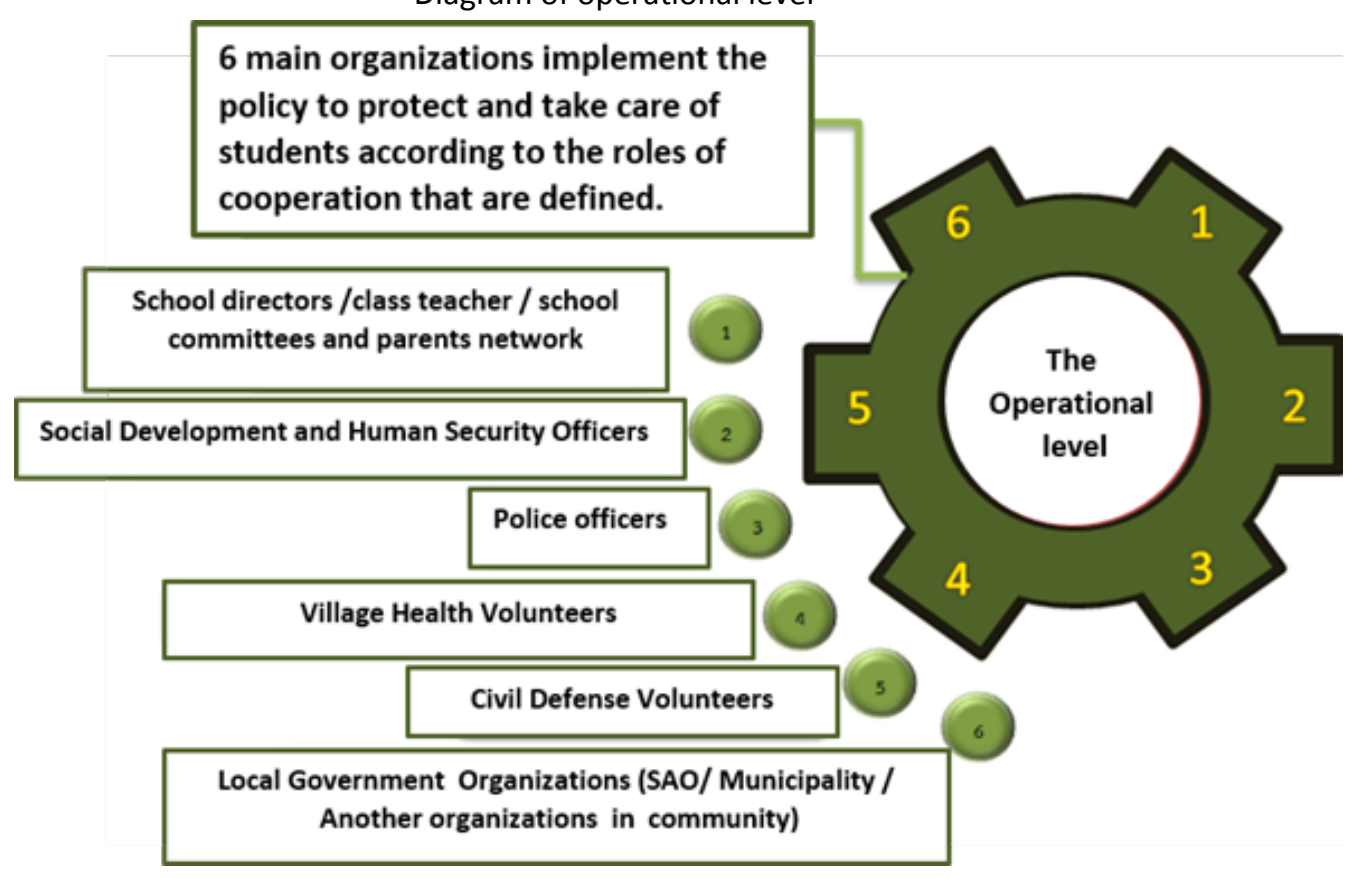

\section{Part 3. Guidelines for using the model}

Guidelines for the implementation of the model are divided into 3 levels as follows:

\subsection{Policy level}

3.1.1 Raising awareness about the protection and care for students to administrators, teachers, education personnel, Board of Directors for Basic Education Schools, and those who are involved and can be applied the policy appropriately.

3.1.2 Developing the team of students' behavior promotion staff to gain knowledge, understanding and skills in performing their duties in accordance with the specified roles because the staff of student behavior promotion is an important mechanism to protect and care for students.

\subsubsection{Evaluate the educational institutions readiness.}

3.1.4 Set up goals for developing and responsible to protect and care for students.

\subsection{Driving Force Level}

3.2.1 Organize meetings and seminars together in order to set goals to protect and care for students.

3.2.2 Prepare manuals to protect and care for students for officer to promote behavior students and other stakeholders who have studied and used them as guidelines to perform appropriately.

3.2.3 Establish a work calendar to protect and care for students. 
3.2.4 Appoint a committee to be responsible for the protection and care for students.

3.2.5 Conduct supervision and follows up to the working calendar.

3.2.6 Provide meetings in order to summarize the protection and care for students once a month to develop and improve for what has been done.

\subsection{Operational level}

3.3.1 Organize meetings and seminars together to set goals to protect and care for students.

3.3.2 Prepare manuals to protect and care for students for officer to promote behavior students and other stakeholders who have studied and used them as guidelines to perform appropriately.

3.2.3 Establish a work calendar to protect and care for students.

3.2.4 Appoint a committee to responsible for the protection and care for students.

3.2.5 Conduct supervision and follow up to the working calendar.

3.2.6 Provide meetings in order to summarize the protection and care for students once a month to develop and improve for what has been done.

\section{Part 4. Conditions for success}

4.1 The organization concerned is responsible for cooperation in the implementation of protection and care for students.

4.2 People who are involved at all levels have to perform their duties with sacrifice and focus on protecting and caring students.

4.3 Ministries, organizations or agencies must concern themselves to care operations in accordance through the corporate chain of command in order to drive the policy systematically and link to the work at each level quickly and efficiently.

\section{Conclusions}

The development of cooperation model for protection and care for students under the Office of the Basic Education Commission. The researcher presents the conclusions as follows.

The development of cooperation model for protection and care for students under OBEC consists of 4 parts as follows: 1 ) introduction that consists of the background, concepts and the objectives of the model model's components which consists of three levels as the policy level, the driven forced level, and operating level 3) guidelines for using this model and 4) conditions for success. Experts have the overall opinion that the model is accurate, appropriate, feasible and useful. Therefore, if the operating cooperation model for protection and care for students under the Office of the Basic Education Commission is supported and passed on to policy-level departments, driving force level, and operating level which is matched to the legal and standardized operating system. This will cause the holistic cooperation that prevents the problems in order to develop full potential to students. The students will have desired characteristics, strong mental immunity and will have a good quality of life including life skills and are safe from any crisis they face.

\section{Discussion and suggestion}

5.1 Guidelines for the cooperation to protect and care for students under the Office of the Basic Education Commission. As for the policy department at the ministry level, a framework for action should be established to 
lead the practitioners to drive and implement operations in order to coordinate, protect and surveil carefully. It is a system of drivers at the regional level that can be able to coordinate the service in accordance with the policy framework, guidelines and missions for school-level practitioners to act appropriately and it is still the next system according to the structure give for the operators to in the working area on time. And additionally, suggestions on education, operating conditions, protection and care for students are mentioned below. There should be a specific strategy for the implementation from OBEC. The results of this study were also supported by the results of Wutkamphol (2014) who studied the Status and Guideline in Developing Students care in the School of Pitsanulok Educational Service Area Office 3. The results of his study showed as follows: There are 5 operational guidelines: 1) Office of Educational Area ,School administrators including helping school administrators in all departments must be aware of the importance of the student care system and also support the operations 2) All teachers and stakeholders need to be aware of the importance of the student care system, have a positive attitude towards students and always feel happy to develop students in all aspects 3) All committees or working committees must worked closely and always have regular meetings . 4) The adviser teachers are the important person who run the policy and they are supported by the school 5) Training and providing knowledge and skills including disseminating information educating teachers, counselors or those involved in matters that contribute to student care is essential, especially on the basic skills and approaches to solving student problems. This should be done continuously and regularly. These results are supported by other related studies such as Sanyear (2013) said that developing human resource is an important process in preparing to increase the quality of the workers both in terms of knowledge and skills. The skills and attitudes in the implementation of the student support system make it possible to see the value of the student care system and to be able to perform responsible work more efficiently that affects the success of the student care system. If the advisor teachers have developed their knowledge continually, they can perform their duties systematically and complete the goals as they intended. Kenwiset (2015) said that if personnel are encouraged to continually develop themselves in the systematic operations, this will encourage responsibility, learning from work, create internal motivation to develop oneself, practice team learning, improve the concept of operating performance including the aim of going to the same destination and develop the ability to achieve the group's objectives. They must create a learning culture by promoting learning abilities, promoting continuous education, using reflections for planning in order to solve problems, build effective learning networks and communicate results to students effectively.

\subsection{The cooperation model for protection and care for students under the Office of the Basic Education} Commission. It is a theoretical model which developed from a theoretical framework as a basis that represents the structure and relationship of the components of the study and the relationship of the elements of the cooperation model, operation, protection and care for students. This was examined by a group of experts who have knowledge and work experience in the protection and care for students Under the Office of the Basic Education Commission. The researcher has conducted this research as research and development by studying the qualitative and quantitative data in order to obtain accurate and clear empirical data. It can be used as a model for co-operation and prevention and care for students Because it is reasonable for the research objectives. More importantly, the model is confirmed by experts who are of the opinion that the model is accuracy, propriety, feasibility and utility. The results are supported by Keeves's concept (1988 cited that stated the fine attributes of a model and must have a relationship of structured variables. It can be used to predict results from empirical data and clearly explains rational phenomena that leads to the creation of new ideas and matches to the studied theory. Peangsawad, (2010) said that the pattern development has 2 steps: 1) creating or developing a pattern and, 2) accuracy of the model and the evaluation of the model is correct, reliable and comprehensive according to real needs. The results are supported by Sritrakul, (2013) who studied the development of student care system management model in schools under the primary educational service area office. The main objective was to assess the constructed management system of student care system in schools under the primary 
educational service area office. The research found the following results: 1 . Study of circumstances and a direction of the student care system management in the schools including principles and concepts of management. The factors that affect are included of establishment and delivery of policies, cooperation of personnel and system management which consisting of planning, organizing, leading, doing, controlling, acting and coordinating. 2. The system management model of student care system management in schools created comprises of three elements : 1) principles and concepts of management, 2) factors affecting the management, consisting of establishment and delivery of policies, and policy driving by the main personnel responsible for the system, and 3 ) the procedures of management, consisting of planning, organizing leading, doing, controlling, acting and coordinating. 3. The assessment of the developed system providing care for students has potential for implementation at a high level, and represents utility at the highest level. According to the study of the development of cooperation model for protection and care for students under OBEC, the school must drive the educational institution level, there should be guidelines for operations as follows prepare information about cooperation in the protection and care for students systematically and up to date. Create activities aimed at promoting and developing students to have life skills and live together in society with quality. To develop teachers and educational personnel to be efficient, cooperation, operation, protection and care for students. Establish a system of engagement with all network partners and agencies involved in developing and solving problems related to cooperation in the protection and care for children. Finally, the school must conduct a summary of the report. And evaluating cooperation in protecting and caring students for continuous improvement.

\section{Bibliographic references}

Bhawangkanantha, T. (2016). Development of a network of cooperation in the operation of protection and care for students Under the Office of the Basic Education Commission. Bangkok: Office of the Basic Education. [in Thai]

Keeves, J.P. (1988). Educational Research Methodology and Measurement. Oxford, UK: Pergamon Press.

Kenwised, P. (2018). "The Development of Linear Structural Relations Model of Factors Affecting Effectiveness of Students Care System in Fundamental Schools". Chophayom Journal Vol.29 No.1 (January-May) 2018.

Ministry of Social Development and Human Security. Social welfare promotion act, B.E. 2546 (2003) and Act (No.2) B.E. 2550 (2007). [in Thai]

Office of the Basic Education Commission, (2014). Handbook for the protection and care for schoolchildren. Specialized Center for the Protection and care for Students. Bangkok: The Agricultural Cooperative Federation of Thailand, Limited. [in Thai]

Office of the Basic Education Commission, (2016). Guidelines for the implementation of the student care system in schools. Specialized Center for the Protection and Care for Students. The Agricultural Cooperative Federation of Thailand, Limited. [in Thai]

Peangsawad, W. (2010). “Developing Model Research”. Rajabhat Sakon Nakhon University Journal, 2(4), 1-15. [in Thai]

Phucharoen, S. (2019). "Strategies for using the satellite distance education system in Thailand that affect student quality of marginal schools in the lower north region". Retrieved May 17, 2021, from https://www.revistaespacios.com/a19v40n41/19404119.html [ISSN 0798 1015]. Vol. 40 (Number 41) Year 2019. Page 19. 
Sanyear, O. (2013). "Factors affecting the effectiveness of the implementation of the student care system of schools under Loei Primary Educational Service Area Office 2". Master's Thesis, Loei Rajabhat University. [in Thai]

Sritrakul, O. (2013). "The Development of Student Care System Management Model in Schools under the Primary Educational Service Area Office". Journal of Education Naresuan University, Year 15, Issue 4, October - December 2013. [in Thai]

Wutkamphol, W. (2014). "A study of conditions and guidelines for the development of the system to care for students in schools under Phitsanulok Primary Educational Service Area Office 3". Master's Thesis, Pibulsongkram Rajabhat University. [in Thai]

Esta obra está bajo una Licencia Creative Commons

Attribución-NoCommercial 4.0 International

\section{(cc) EY-NC}

